\title{
Editorial \\ A new research agenda for decentering public leadership
}

\begin{abstract}
This article sets out a new research agenda for decentered public leadership. Nested in the concept of decentered theory, it examines the messy and contested nature of public leadership practices in different contexts. Drawing on recent empirical studies that have adopted a decentered approach to examining public leadership, it sets out a future research agenda that places individuals, history and context at the heart of explanations for public leadership in action.
\end{abstract}

\section{Introduction}

This special issue on "Decentering Public Leadership" explores the messy and contested nature of public leadership practices by drawing on qualitative and interpretivist accounts in the tradition of storytelling in different leadership settings. In doing so, it offers an alternative to positivist, rational choice explanations for the social world and for public leadership. Nested in the concept of decentered theory, it explores our understanding of public leadership through the lens of humanist and historical practices that take place within temporal and contested contexts. This special issue informs our understanding of the complexities of public leadership in contemporary policy making and offers a future research agenda for decentering public leadership.

The article begins by providing an overview of decentered theory, drawing particular attention to four key characteristics that are pertinent to the study of public leadership. Next, it examines the position of decentering public leadership within the mainstream public leadership literature. The following section outlines the contributions of this special issue. Each contribution takes a decentered approach to the study of public leadership to offer new and exciting reflections on the performative aspects of leadership. The authors gathered here engage with different if overlapping aspects of decentered theory. They showcase an array of focal points for decentered studies of leadership and point to an emergent and exploratory research agenda that places agency and history (as opposed to institutions and neoliberal thinking) at the heart of understanding public leadership in action. The article concludes by offering a series of avenues for future research on decentered public leadership.

\section{Decentred theory}

Decentered theory places emphasis on the diverse meanings - elite narratives, social science rationalities and local traditions - that inspire governing practices across time, space and the policy sector. The state and public policy consist, in this view, of a vast array of meaningful actions as they coalesce into contingent, shifting and contestable practices. Scholars often define governance in contrast to government: whereas government is about bureaucracy, governance is about markets and networks. This view of governance has led to vigorous debates about whether the state has been hollowed out, whether the number of networks has risen and whether the state can still steer effectively. Although these debates cast light on some issues, they suggest an overly monolithic view of governance.

By contrast, decentered theory rethinks governance not as a particular state formation, but as the variegated policies and practices associated with the impact of modernist social science on policymaking. Decentered theory views the state as always and inherently made

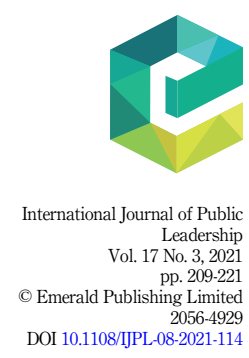


IJPL

17,3

\section{0}

up of different and competing actors inspired by different beliefs and traditions. Four key aspects of decentered theory are viewed as particularly illuminating when seeking to understand the complexities and nuances of public leadership in contemporary policy settings, most notably,

(1) a humanist and historicist understanding of social life;

(2) the pursuit of realistic and naturalistic alternatives to rationalist interpretations of reality;

(3) a focus on the complexities of an interconnected reality; and

(4) the importance of beliefs, practices, traditions and dilemmas in the study of public policy.

Each of these is discussed in turn below.

\section{A humanist and historicist understanding of social life}

The idea of decentering has gained prominence through its connection with a "decentered theory" that is associated with the concept of the stateless state (Bevir, 2003, 2013; Jessop, 2016; Peters, 2016; Ranson, 2012; Robichau, 2011; Turnbull, 2018; Ungsuchaval, 2016). The stateless state purports that the state is always and inherently made up of different and competing actors inspired by different beliefs and traditions. As a result, it treats the idea of the hollow state as an empirical hypothesis: the state may have lost power in some places and some policy areas, but social scientists should no more treat hollowing out as a reified and inevitable social process than they should reify the state. In keeping with notions of a stateless state, decentered theory is humanist in presenting social life as a human activity informed by the agency and reasoning of actors (not institutional structures). It is also historicist in presenting agency and reasoning as occurring against historical backcloths that influence them.

\section{A focus on realistic and naturalistic interpretations of reality}

Decentered theory unpacks governance and associated practices, such as public leadership, as meaningful activities. To discuss and explain these in this way is to ascribe desires and beliefs to the realities of relevant actors. Actions can be understood only in terms of the intentionality of the actors. Unlike rational choice theory, for example, decentered theory emphasizes the holistic and contingent nature of intentionality. This philosophical approach lends itself to rich, interpretivist methods for investigation. Indeed, researchers must do the empirical work of finding out what beliefs and desires people hold in any given case. They, therefore, rely less on formal models than on contextual and historical explanations. Thus, decentered theory concentrates not only on the construction of practices as people act on beliefs but also on the narratives and traditions that provide the context and historical background to people's beliefs and actions. Decentered theory provides governance scholars with an alternative micro theory to that associated with rational choice theory.

\section{Understanding the complexities of an interconnected reality}

Whereas modernist social science characteristically isolates atomistic aspects of human life, decentered theory pursues the complexities of an interconnected reality and naturalistic accounts of concrete activity. For example, a key challenge facing the study of public leadership in governance settings is the analysis of power. Mid-level theorists often want to ignore the micro level and focus on institutions and structures precisely because they believe that power is an important structuring force within social relations. Some mid-level theorists 
argue that concepts such as "differentiated polity" and "network governance" do not allow for the way in which power structures governance (Marsh, 2008, 2011). Decentered theory offers a response to this challenge in so far as it encourages social scientists to rethink power as a force lacking any center (Foucault, 1982; Torfing, 2009). If power refers to the ways in which the actions of others define what any individual can and cannot do, then power appears throughout state action.

Power appears wherever people connect, interpret and respond to one another. Every actor is both enabled and constrained by the actions of others in an interconnected reality. Prime ministers, senior civil servants, doctors, police officers and everyday citizens all find their possibilities for action restricted by what others do. So, concepts like "differentiated polity" and "hollow state" rightly emphasize the diverse ways in which other actors thwart the intentions of the center. Governance scholars show how local actors - local mayors, education managers, management consultants - intentionally and unintentionally resist the core executive.

When decentered theory invokes a fragmented state, it points to a postfoundational critique of reified concepts of the state for their neglect of the varied contingent meanings and activities that make up the state. As we have seen, it implies less that bureaucracy has declined and networks grown than that the state is and always has been stateless. States have no essence, structural quality or power to determine the actions of which they consist. The state is just an aggregate description for a vast array of meaningful actions that coalesce into contingent, shifting and contested practices. The complexities and interconnectivity of these actions is central to understanding decentered public leadership in practice.

\section{The importance of beliefs, practices, traditions and dilemmas in the study of public policy}

When decentered theory addresses changes in the state, it does not presuppose a decline in hierarchies and a rise in networks alluded to in governance theory (Capano, 2011; Capano et al., 2015; Davies, 2000; Goetz, 2008; Holliday, 2000; Richardson, 2018; Taylor, 2000). Indeed, it offers a critique of any attempt to reify these concepts. Instead, decentered theory is interested in how the spread of new ideas and beliefs about markets and networks lead to changes in the state. Decentered theory, therefore, encourages studies of the myriad ways in which local actors have interpreted these discourses and policies, responded to them, resisted the intentions of the elites, and forged their own practices. Decentered theory highlights the importance of beliefs, practices, traditions and dilemmas for the study of public leadership in different contexts.

A decentered approach replaces formal modernist accounts of the state with a historical narrative suggesting that the currently dominant approaches to social organization embody a contingent modernist form of expertise, and that this modernist expertise is undermined by not properly allowing for its own historicity. Modernist social science inspires defenses of state planning, markets, free markets and networks. It implies that one or other of these organizational types is, at least under specified circumstances, ideally rational. By contrast, decentered theory foregrounds the inherent contingency and contestability of human activity and so the variety and unpredictability of organizations and leadership action.

Consequently, decentered theory contrasts with modernist social science. It rejects projects which seek to unpack the essential properties and necessary logics of social and political life. It suggests that neither the intrinsic rationality of markets nor the path dependency of institutions properly determines the forms of state activity. It conceives of public policies as contingent constructions inspired by competing beliefs and rooted in different traditions. Decentered theory explains shifting patterns within public settings by focusing on the actors' own interpretations of their actions and practices and by locating these interpretations in historical contexts. Most fundamentally, it shifts the focus from institutions to meanings in action. In displacing institutions, it suggests the state is stateless. 
IJPL

17,3

This account of decentered theory raises important questions for the study of public leadership in contemporary contexts. The following section sets out some of the dominant thinking guiding public leadership research and examines how decentered public leadership sits within it.

\section{Decentering public leadership and its place within mainstream leadership theory}

Though leadership is often thought to be at the heart of public administration, a series of stock-taking reviews of the field at the start of the millennium found public leadership research to be "meagre" (Kellerman and Webster, 2001, p. 485), "muted and underdeveloped" (Van Wart, 2003, p. 223), and lacking the maturity of leadership in related fields (Trottier et al., 2008). Such reviews perhaps underplay more recent public leadership research that cuts across multiple fields and disciplines (Hartley, 2018; Vogel and Werkmeister, 2021). Indeed, research on public leadership has expanded significantly in the past decade alone.

Scholars, not least in this journal, have explored public leadership as a collective (Miao and Ju, 2020; Torfing et al., 2019), multilevel (Capler, 2020), and highly relational (McClellan, 2020) endeavor. Furthermore, they have developed an appreciation of leadership as imbued with public values (Cao et al., 2018), pointing to particular ethical dimensions (Hattke and Hattke, 2019; Ozsungur, 2020) of public leadership. The following discussion identifies several areas where the public leadership literature has developed over recent years and where there is some commonality and contradiction with a decentered approach, most notably:

(1) public values;

(2) narratives and storytelling;

(3) distributed and collaborative leadership;

(4) relational leadership.

Each of these aspects of public leadership is now discussed in turn.

\section{Public values}

For some scholars, attention to public value is a distinguishing feature of public leadership. The Minnowbrook meeting in 2008 resulted in a manifesto inviting scholars to make the study of the distinctiveness of public leadership a central focus of public administration research. Here public leadership is understood as being values-based. It is "leadership for the common good, for the purpose of creating public value" (Getha-Taylor et al., 2011, p. i84). Such calls, alongside earlier critiques, helped to stimulate leadership research that seeks to understand the specificities of goals, culture, context and practice within public sector organizations. In this way, Kouzes and Posner describe leadership as "the art of mobilizing others to want to struggle for shared aspiration" (2002, p. 24). Moore (2014) emphasizes the role of public administration pursuing public value in relation to common good. Wright, Moynihan and Pandey point out "the inspirational power of public missions is not a given; it needs to be cultivated" (2012, p. 212). In this stream of research, public leaders harness the motivating power of worthwhile organizational goals by "highlighting and rewarding public service values" (Perry and Hondeghem, 2008, p. 309). In this way, for Hartley (2018, p. 203), public leadership is: "mobilizing individuals, organizations and networks to formulate and/or enact purposes, values and actions which aim or claim to create valued outcomes for the public sphere". The focus on values echoes a commitment in decentered theory to focus on the beliefs, practices, traditions and dilemmas in context. However, unlike much of the mainstream public leadership literature identified above, decentered theory does not give 
prominence to the institutional structures within which values are created, contested and reformulated.

\section{Narratives and storytelling}

Alongside work on public value, there has been a developing interest in how shared meanings are created in organizations through narratives or stories that make sense of complexity and change (Borins, 2011; Sternberg, 2008). A turn to narrative also points us toward the ways in which public organizations are fueled by stories that offer compelling accounts of the past, the present and the future and act as a basis for mediating the collective, relational action of organizational life. Orr and Bennett (2017), for example, have argued that leadership influence and control can be exercised effectively through expressive narratives and storytelling. This involves making an emotional connection with people to exert influence through a collaborative endeavor, rather than employing bureaucratic authority. Indeed, this feature of political leadership was explored by Ayres (2021) in her decentered analysis of informal decision-making in Whitehall, whereby social relationships were used to exert control as opposed to hierarchy. Indeed, the literatures on informal governance and decentered theory are natural bedfellows. Both draw attention to the importance of situated actors in shaping public action. Decentered theory advocates social scientists listening to the narratives and stories of those they study to construct their own narratives "as an insightful way of analyzing governance" (Bevir, 2013, p. 8). Likewise, the literature on informal governance argues that much can be learned about ways to improve public leadership by understanding what happens based on the perceptions and narratives of actors involved (Ayres, 2019). Nonetheless, while the mainstream public policy and leadership literature recognize the importance of understanding the realities of public leadership through storytelling and narrative, they often seek to appraise public leadership against a set of normative assumptions about where power, legitimacy and accountability lie in relation to the state. Instead, decentered theory encourages social scientists to rethink power as a force lacking any center and to embrace the complexities and interconnected realities shaping public leadership in action.

\section{Distributed and collaborative leadership}

Public leadership scholars have become interested in ideas of collective, distributed and shared leadership as counterpoints to the historical dominance of individualistic, heroic savior leaders. Views of public leadership which emphasize collaborative process and relationality have extended understanding beyond traditional hierarchical assumptions about leadership and away from the public choice elements of new public management. Collective leadership theories view leadership as emerging collaboratively from dyadic relationships and networks. The relational turn has also offered a challenge to the dominance of logical positivist methods. Van Wart's (2013a, b, p. 522) work on public leadership focuses on "the people (at all levels) and the accompanying processes and networks that lead, manage, and guide government and non-profit agencies". The way in which this definition understands the significance of networks rather than reified institutions of governance is in sympathy with a decentering approach. The turn to governance has had implications for the study of public leadership. It became clearer that the traditional focus on state actors and processes is inadequate for understanding the dynamics and settings for leadership. This shift has led to calls for work which focuses on "the range of actors and processes which influence the public sphere" (Hartley, 2018, p. 204).

\section{Relational leadership}

Since its inception, the study of leadership has been highly normative, focusing on finding the best way in which to lead. The origins of this work lie with "great man" or "great person" 
IJPL

17,3

214

theories, a tradition which still finds contemporary echoes. The study of leadership progressed through an interest in style and behavior through to contingency theories which recognized that context matters - a consideration underscored by decentered theory. More recently, important scholarship has examined how leadership is emergent and disembodied (Ford, 2010; Wilson, 2016) or even "spectral" (by which is meant the significance of people who may have departed the organization but whose presence continues to linger) in its manifestations and affects (Pors, 2016; Orr, 2014). This work has developed alongside critical leadership studies which examines, for example, the role of leadership discourse and practice in buttressing patterns of exploitation (e.g. Collinson, 2005, 2006; Tourish, 2019), and work which problematizes the very concept or ontology of leadership (Kelly, 2014).

Fairhurst and Uhl-Bien (2012) highlight the relational nature of leadership: how leaders and followers co-create meaning through interconnected relationships in highly interactive contexts. Ospina (2017, p. 281) contributes a view of collective leadership as an "emergent, interactive process intended to cultivate group members" capacity and adaptability to navigate complexity. Such emphases on relationality and networks complement a decentering approach to the study of leadership. Examining practices through a relational lens moves the analysis beyond the notion of the "hero leader" and instead enables us to explore the ways in which the everyday dilemmas of organizing are inescapably collective. In a decentering move, such work extends the focus beyond bureaucratic office holders or those in formal leadership positions to include a wider range of actors and contexts implicated in shaping the public sphere.

The following section introduces the five empirical contributions to this special issue, demonstrating how a decentered approach to public leadership can offer illuminating insights that seek to complement and extend existing conceptions and understandings of public leadership.

\section{A decentered approach to the empirical investigation of public leadership: an overview of contributions in this special issue}

The collection of articles which this special issue on decentered leadership brings together draws upon critical perspectives of leadership. This body of work shows the different ways in which a decentered approached to leadership can be developed and can contribute to the field of public leadership.

\section{Performative seduction: how management consultants influence practices of leadership}

Ford and Harding (2021) examine how a policy introduced by management consultants became an important part of leadership practice. In the context of a wider trend in the UK public sector, they demonstrate how talent management became embedded in the National Health Service, shaping expectations about everyday leadership practices and strategic leadership development. Ford and Harding's article highlights the significance of the role of management consultants as part of contemporary governance: "Management consultancy is a vast business whose influence reaches deeply into public and private sector organizations around the world" (p. x). Their study suggests the ambiguous, perhaps shadowy, space that management consultants occupy in decentered governance.

The compelling analysis shows how these actors appear to exert considerable impacts on policies and practices, and yet do so in ways which are less than transparent. Relying on what Ford and Harding theorize as strategies of "performative seduction" they have succeeded in impressing upon leaders the importance of the concept of talent management. The case of talent management offers a rich example of how management consultants influence public sector leadership through the incorporation of their services and products into the local 
definitions and everyday performance of public leadership. Their study of the role of management consultants adds momentum to decentered inquiry which seeks to appreciate the motley array of policies and practices that constitute contemporary modes of governance.

Editorial

Leadership without "the led": a case study of the South Wales Valleys

Nancy Harding's (2021) article develops a "theory of insouciance" toward public service leadership. "Insouciance" is interpreted to mean indifference or lacking any interest in or concern about an issue. Harding's powerful and deeply personal article disrupts assumptions about leadership by showing how those who are conventionally portrayed as "followers" may be, at best, indifferent toward those people labeled as "leaders". In doing so, the analysis contributes to "anti-leadership" theories, opening alternative ways of conceptualizing and theorizing everyday relationality and influence. Providing a case study of the South Wales Valleys, Harding uses an innovative and immersive research methodology, influenced by feminist, post-qualitative and post-human research methods, to examine community-level meanings of leadership.

The study highlights expressions and roots of community resistance to ideas and practices of public leadership and the domain of governance. Neo-liberalist expressions of leadership are at odds with more communitarian traditions. The public sector should provide services; it is not a sphere of governance. The case identifies neo-communitarian cultures which are skeptical about leadership and leaders and resistant to hierarchical norms. Harding's analysis of historical traditions shows how webs of meaning act as a backcloth to the contemporary politics. A sense of history in which leaders have been deemed guilty of betrayal or exploitation of communities hangs heavy in the air. As Harding describes, "leadership" belongs in that other, alien sphere and lacks meaning in the lived domain' (p. 10). Moreover, Harding concludes that the very concept of leadership'... .carries with it hints of a colonialism that has been sensed and resisted' (p. 10) Methodologically, Harding's study points the way toward leadership studies which embrace emerging forms of qualitative research to generate insights that problematizes universalizing theories of public leadership and followership.

\section{Local meaning-making in discursive, embodied and affective registers}

Justine Grøbæk Pors' (2021) article provides a fascinating ethnographic study of a leadership development program run in a Danish local government. It explores the question of how public leaders navigate complex policy transformations. Pors analyzes the embodied and affective aspects of the local meaning-making - how leaders make sense of complexity and frame its meaning for others - work of leaders. The study both adds to public leadership scholarship on meaning-making and challenges mainstream understandings of leadership as individual, disembodied and rational. It highlights local resistance through attention to how public policies find expression in local vernaculars. It helps us appreciate that local settings are an "ongoing tangle" of traditions, competing narratives and actors. The article contributes to scholarship on decentered public leadership by highlighting the way multiple traditions shape local policy and practice and by providing a nuanced and sensitive reading of the ongoing and contingent processes through which actors interpret and reinterpret policy. Pors' study highlights how leadership can be understood as a lived and embodied practice, and calls attention to the affective dimensions of leadership work.

The ethnographic fieldwork takes place in after-school care institutions in Denmark. Zooming in on a particular conversation that took place during a management development session, she examines how anxieties bubble to the surface among participants, thus resisting the discursive frames provided by senior organizational leaders. This approach goes beyond a mundane understanding of public sector professionals being involved in emotional or empathetic work. Instead, it focuses on affective episodes as points of inquiry. Focusing on 
IJPL 17,3

moments of affect can help an analytical appreciation of the "unpredictable and ungovernable" aspects of meaning-making practices. The study shows how a complexity of meaning-making processes lie beneath elite leadership narratives and champions the complexities of interconnected reality espoused by decentered theory.

\section{Navigating three faces of decentred leadership in the UK Parliament}

Mark Bennister's (2021) article connects public leadership with theories of decentered governance. His ethnographic study of the Westminster Parliament highlights the multifaceted dimensions of the institution, highlighting a lack of cohesion and collective direction. In a decentered analysis, Bennister problematizes the idea of a structured public institution and his anti-foundationalist approach shows instead how there are multiple, contested sites of leadership and governance. He focuses on the concept of "legislative leadership", to better understand what goes on within parliamentary settings. As Bennister points out, legislative leadership has been a somewhat neglected area of public leadership research, perhaps as it has tended to sit outside organizational theory studies and political studies. The ethnographic fieldwork, combing observations and interviews, examines the everyday practices of Westminster and benefits from remarkable and privileged access gained through Bennister's academic fellowship in the UK Parliament. His research involved being immersed in the day-to-day work of the parliament and allowed close observation of the Speaker of the Commons and the Speaker of the Lords.

His article shows how parliaments are sites of contestation. Though they are places of symbolic and ritualized behavior, leadership action is also accomplished through a warren of leadership networks and relationships. Bennister thus argues that legislative leadership can be understood as "a diverse and decentered activity, contingent on actors' beliefs, circumstance and traditions" (p. 10). His disaggregation of leadership practices in the parliament provides a conceptualization of the "three faces" of legislative leadership: the procedural, the governance and the place-based external factors. Resisting the ostensible formality of the institution, Bennister's analysis emphasizes the rich contingencies of leadership action. The study points to the value of examining elite behavior in the legislature, as elsewhere, from an ethnographic perspective.

\section{Localpoliticalleadership: from managerialperformances to leaders-hip hop on socialmedia?}

Alessandro Sancino's (2021) article provides us with a story-based approach to illuminate the emergence of new leadership traditions in local government in Italy. He asks: how have the leadership practices of local political leaders evolved in the last decade? The study examines the development of leadership practices performed by local political leaders and proposes some new theoretical concepts to make sense of these changes. The fieldwork focuses on the role of executive local political leaders, councilors who have decision-making responsibilities. Echoing Ford and Harding's (2021) article, as well as Harding's (2021) observations about the re-casting of local government in the Welsh Valleys, Sancino notes the wider move toward new public management based on a critique of local councils as inefficient and old fashioned. Sancino's background which has involved holding a series of senior political roles in the region, gave him unique and wonderful access to the setting. This meant that he was able to draw upon his own auto-ethnographic experience, as well as participant and nonparticipant observation and interviews.

This story tells of the ascendancy of social media as a decentering arena for local politics. Sancino's study highlights the importance of relational leadership accomplished through face-to-face interactions, but also an emergent "shift in the dominant technologies of local political leadership from the logics of managerialism towards the logics of social media" (p. 10). The analysis emphasizes the performative dimensions of local public leadership. He 
connects this with approaches to the study of leadership which emphasizes the aesthetic and sometimes artistic dimensions of leadership. His research adopts an ethic of playfulness to create an innovative concept of "leaders-hip (hop)" to represent how local politicians engage in "leadership performances" on social media. The theater of local politics is thus extended from the town hall to digital spaces. The metaphor of hip hop connects with traditions of spoken word performances about society and politics performed in front of groups. Shaking hands with people in local pubs, or greeting people in the piazzas, is now supplemented, even overtaken, by the importance of posting messages and videos on social networks. His article ends by identifying practical implications for local political leaders as well as methodological reflections on how research which focuses on storytelling can advance comparative decentered leadership scholarship.

\section{Conclusion: a future research agenda for decentering public leadership}

The articles in this collection show how decentering public leadership can offer critical and illuminating accounts of public leadership in action. These accounts reflect the day-to-day realities of public leaders seeking to exert control in temporal and contested spaces in interaction with others. The collection of articles in this issue takes a critical approach to leadership by engaging with voices and actors often excluded from mainstream studies of public leadership. In doing so, the authors highlight the opportunity for public leadership studies to attend to ethical questions. What is at stake in a talent management initiative, a policy change, the authoring of accounts of political divisions, the shift to social media as a platform for local dialog, or the dance between formal traditional and local networks in the parliament? The answers to these questions, found in the collection of articles here, unsettle orthodox assumptions about the legitimacy of management and leadership authority, and alter our sense of whose voices should matter when undertaking public leadership research.

Ford and Harding direct us to the imbalances of voice and influence in the health sector, to the iniquitous impacts of grand modernizing organizational strategies and to how local public managers can become subordinated to market interests. Harding highlights the vibrancy and power of voices in the community all too often assumed to be acquiescent recipients of the decisions of their "superiors". Pors shows how our understanding of the implementation of policy initiatives needs to attend to the perspectives of those at the front line rather than the just the legislators or executives often assumed to be directing events from above. Bennister's work highlights the everyday work of parliamentarians beyond the grand office of the Speaker and points to the liveliness of local networks of relationality that researchers need to engage with to understand legislative leadership. Finally, Sancino's study extends our focus to the digital sphere to explore the technologically-mediated dialogs involving members of the community in shaping local politics and the performance of leadership.

Together, these articles embrace decentered leadership studies through engaging with a diversity of settings: the executive boardrooms and sales pitches of talent management consultants, bar-room discussions of Brexit in the postcolonial Welsh Valleys, politicians glad-handing in Italian piazzas only to be interrupted by late-night social media storms, the pomp and circumstance of Westminster being circumvented by quiet relational work accomplished through networks, and the powerful, upending moments of affect during management training courses in Denmark, when leaders' discursive framings of organizational changes are disrupted or overturned.

All the studies embrace an appreciation of the action "beneath and beyond" institutional or elite-level analyses. Indeed, in the case of Harding and Sancino they extend the focal points for decentered inquiry into the very communities that are often assumed to be the "subjects" of leadership and governance, or into emerging digital spaces. All the contributors provide excellent examples of how ethnographic work can further decentered scholarship. 
IJPL

17,3

218

Both Harding and Pors use methodologies which raise awareness of the options available in the study of public leadership, lighting the way for work which is informed by the affective turn in the humanities, as well as feminist, post-qualitative and post-human methods.

This exploration into the contribution of decentered public leadership suggests several avenues for future research on public leadership. At this point we return to the key features of decentered theory, introduced at the start of this article, and draw out their significance for the future study of public leadership.

First, a humanist and historicist understanding of social life offers the potential to critically engage with leaders' narratives and stories and surface the ethical considerations involved in leaders' discursive strategies of influence. It can draw from different disciplines to build decentered understandings of leadership, including the timely need to take great account of gender, race and class that are currently so dominant in social narratives. Finally, this approach can explore how leadership is accomplished in technologically mediated ways, including at times when colleagues are dispersed or working in more remote circumstances a situation that has now become more common due to changes in working practices brought about by the coronavirus disease 2019 (COVID-19) pandemic.

Second, the pursuit of realistic and naturalistic alternatives to rationalist interpretations of reality requires methodologically innovative work which utilizes a spectrum of qualitative methods, including narrative and discourse inquiry, ethnographic, shadowing and observational work. Indeed, these rich, interpretivist approaches are in stark contrast to much of the quantitative work that dominates so much of the mainstream leadership literature. Rich qualitative methods are shown to be an effective way to extend an interest in public leadership to the dynamics within communities and constituencies often assumed to be the passive recipients of leadership action. They can also be employed to understand the complexities and nuances of distributed and collaborative leadership within and across organizations, and beyond hierarchies and rank-based assumptions of leadership influence.

Third, a focus on the complexities of an interconnected reality builds on relational studies of leadership and examines leadership being accomplished through networks of relations. It also offers scope to utilize decentered theory to understand how public leadership engages with grand societal challenges, such as climate change, sustainability, economic and social inequality and democratic renewal.

Finally, acknowledging the importance of beliefs, practices, traditions and dilemmas problematizes the simple dichotomy of leadership and followership and explores instead more reflexive understandings of leadership dynamics, including resistance and disruption. It acknowledges the traditions of leadership in public sector settings, traces their lineage and examines the public leadership dilemmas that arise from these historical influences.

Sarah Ayres, Mark Bevir and Kevin Orr

\section{References}

Ayres, S. (2019), "How can network leaders use soft metagovernance to promote public value", Public Administration, Vol. 97 No. 2, pp. 279-295.

Ayres, S. (2021), "A decentered assessment of the impact of informal governance on democratic legitimacy", Public Policy and Administration Special Issue, (Forthcoming).

Bennister, M. (2021), "Navigating three faces of decentred leadership in the UK Parliament", International Journal of Public Leadership, Vol 17 No 3, pp. 265-282, doi: 10.1108/IJPL-062020-0058.

Bevir, M. (2003), "A decentred theory of governance”, in Bang, H. (Ed.), Governance as Social and Political Communication, Manchester University Press, Manchester, pp. 200-222. 
Bevir, M. (2013), A Theory of Governance, University of California Press, Berkeley, CA.

Borins, S. (2011), "Making narrative count: a narratological approach to public management innovation”, Journal of Public Administration Research and Theory, Vol. 22 No. 1, pp. 165-189.

Cao, Z., Anderson, V., Xu, F. and Caldwell, C. (2018), "Understanding Chinese students' values insights for tomorrow's managers", International Journal of Public Leadership, Vol. 14 No. 2, pp. 119-136.

Capano, G. (2011), "Government continues to do its job: a comparative study of governance shifts in the higher education sector", Public Administration, Vol. 89 No. 4, pp. 1622-1642.

Capano, G., Howlett, M. and Ramesh, M. (2015), "Bringing governments back in: governance and governing in comparative policy analysis", Journal of Comparative Policy Analysis, Vol. 17 No. 4, pp. 311-321.

Capler, J. (2020), "A descriptive case study of effective decision-making of a local government organization in the United States of America", International Journal of Public Leadership, Vol. 16 No. 3, pp. 279-297.

Collinson, D. (2005), "Dialectics of leadership”, Human Relations, Vol. 58 No. 11, pp. 1419-1442.

Collinson, D. (2006), "Rethinking followership: a post-structuralist analysis of follower identities", The Leadership Quarterly, Vol. 17 No. 2, pp. 179-189.

Davies, J. (2000), "The hollowing-out of local democracy and the 'fatal conceit' of governing without government", British Journal of Politics and International Relations, Vol. 2 No. 3, pp. 414-428.

Fairhurst, G.T. and Uhl-Bien, M. (2012), "Organizational discourse analysis (ODA): examining leadership as a relational process", The Leadership Quarterly, Vol. 23 No. 6, pp. 1043-1062.

Ford, J. (2010), "Studying leadership critically: a psychosocial lens on leadership identities", Leadership, Vol. 6 No. 1, pp. 47-65.

Ford, J. and Harding, N. (2020), "Performative seduction: how management consultants influence practices of leadership", International Journal of Public Leadership, Vol 17 No 3, pp. 222-235, doi: 10.1108/IJPL-07-2020-0062.

Foucault, M. (1982), "Afterword: the subject and power”, in Dreyfus, H., Rabinow, P. and Foucault, M. (Eds), Beyond Structuralism and Hermeneutics, University of Chicago Press, Chicago, pp. 208-226.

Getha-Taylor, H., Holmes, M., Jacobson, W., Morse, R. and Sowa, J. (2011), "Focusing the public leadership lens: research propositions and questions in the Minnowbrook tradition", Journal of Public Administration Research and Theory, Vol. 21 Special Issue, pp. i83-i97.

Goetz, K. (2008), "Governance as a path to government”, West European Politics, Vol. 31 Nos 1-2, pp. 258-279.

Harding, N. (2021), "Leadership without "the led": a case study of the South Wales Valleys", International Journal of Public Leadership, Vol 17 No 3, pp. 236-246, doi: 10.1108/IJPL-072020-0063.

Hartley, J. (2018), “Ten propositions about public leadership”, International Journal of Public Leadership, Vol. 14 No. 4, pp. 202-217.

Hattke, F. and Hattke, J. (2019), "Lead by example? The dissemination of ethical values through authentic leader inspiration", International Journal of Public Leadership, Vol. 15 No. 4, pp. 224-237.

Holliday, I. (2000), “Is the British state hollowing out?", Political Quarterly, Vol. 71 No. 2, pp. 167-176.

Jessop, B. (2016), "State theory", in Ansell, C. and Torfing, T. (Eds), The Handbook on Theories of Governance, Edward Elgar, Cheltenham, pp. 71-85.

Kellerman, B. and Webster, S.W. (2001), "The recent literature on public leadership reviewed and considered”, The Leadership Quarterly, Vol. 12 No. 4, pp. 485-514. 
IJPL

17,3

Kelly, S. (2014), "Towards a negative ontology of leadership", Human Relations, Vol. 67 No. 8, pp. 905-922.

Kouzes, J.M. and Posner, B.Z. (2002), The Leadership Challenge, 3rd ed., Jossey-Bass, San Francisco.

Marsh, D. (2008), "Understanding British governance: analysing competing models", British Journal of Politics and International Relations, Vol. 10 No. 2, pp. 251-268.

Marsh, D. (2011), "The new orthodoxy: the differentiated polity model”, Public Administration, Vol. 1 No. 89 , pp. $32-48$.

McClellan, S. (2020), "Leading with humility in tumultuous times: evidence from the United States", International Journal of Public Leadership, Vol. 16 No. 3, pp. 265-277.

Miao, T. and Ju, H. (2020), "Leading small groups in China's inter-city governmental cooperation", International Journal of Public Leadership, Vol. 16 No. 2, pp. 249-264.

Moore, M.H. (2014), "Public value accounting: establishing the philosophical basis", Public Administration Review, Vol. 74 No. 4, pp. 465-477.

Orr, K. (2014), "Local government chief Executives' everyday hauntings: towards a theory of organizational ghosts”, Organization Studies, Vol. 35 No. 7, pp. 1041-1061.

Orr, K. and Bennett, M. (2017), "Relational leadership, storytelling and narratives: practices of local government chief executives", Public Administration Review, Vol. 77 No. 4, pp. 515-527.

Ospina, S.M. (2017), "Collective leadership and context in public administration: bridging public leadership research and leadership studies", Public Administration Review, Vol. 77 No. 2, pp. 275-287.

Özsungur, F. (2020), "The effects of ethical leadership on work engagement, intrapreneurship, and service innovation behavior: sample of chambers of commerce and industry", International Journal of Public Leadership, Vol. 16 No. 2, pp. 199-216.

Perry, J.L. and Hondeghem, A. (2008), "Building theory and empirical evidence about public service motivation”, International Public Management Journal, Vol. 11 No. 1, pp. 3-12.

Peters, B. (2016), "Governance is where you Find it", Asian Journal of Political Science, Vol. 24 No. 3, pp. 309-318.

Pors, J.G. (2016), "It sends a cold shiver down my spine: ghostly interruptions to strategy implementation”, Organization Studies, Vol. 37 No. 11, pp. 1641-1659.

Pors, J.G. (2020), "Local meaning-making in discursive, embodied and affective registers", International Journal of Public Leadership, Vol 17 No 3, pp. 247-264, doi: 10.1108/IJPL-062020-0053.

Ranson, S. (2012), "Remaking spaces for civil society", Critical Studies in Education, Vol. 53 No. 3, pp. 245-261.

Richardson, J. (2018), “The changing British policy style: from governance to government”, British Politics, Vol. 13, pp. 215-233.

Robichau, R. (2011), "The mosaic of governance: creating a picture with definitions, theories, and debates", Policy Studies Journal, Vol. 39 No. S1, pp. 113-131.

Sancino, A. (2021), "Local political leadership: from managerial performances to leaders-hip hop on social media?", International Journal of Public Leadership, Vol 17 No 3, pp. 283-297, doi: 10.1108/ IJPL-01-2021-0001.

Sternberg, R.J. (2008), "The WICS approach to leadership: stories of leadership and the structures and processes that support them", The Leadership Quarterly, Vol. 19 No. 3, pp. 360-371.

Taylor, A. (2000), "Hollowing out or filling in? Task forces and the management of cross-cutting issues in British government", British Journal of Politics and International Relations, Vol. 2 No. 1, pp. $46-71$.

Torfing, J. (2009), "Power and discourse: towards an anti-foundationalist concept of power", in Clegg, S. and Haugaard, M. (Eds), The Sage Handbook of Power, Sage, London, pp. 108-124. 
Torfing, J., Sørensen, E. and Bentzen, T.O. (2019), "Institutional design for collective and holistic political leadership", International Journal of Public Leadership, Vol. 15 No. 1, pp. 58-76.

Tourish, D. (2019), "Making a difference: doing leadership research that matters", Journal of Management and Organization, Vol. 25 No. 3, pp. 364-369.

Trottier, T., Van Wart, M. and Wang, X. (2008), "Examining the nature and significance of leadership in government organization", Public Administration Review, Vol. 68 No. 2, pp. 319-333.

Turnbull, N. (Ed.), (2018), Interpreting Governance, High Politics, and Public Policy: Essays Commemorating Interpreting British Governance, Routledge, London.

Ungsuchaval, T. (2016), "Transcending the institutionalist-interpretivist binary: realizing critical realist theory of governance as metagovernance", Journal of Government and Politics, Vol. 7 No. 4, pp. 662-696.

Van Wart, M. (2003), "Public sector leadership theory: an assessment", Public Administration Review, Vol. 63 No. 2, pp. 214-228.

Van Wart, M. (2013a), "Lessons from leadership theory and the contemporary challenges of leaders", Public Administration Review, Vol. 73 No. 4, pp. 553-565.

Van Wart, M. (2013b), "Administrative leadership theory: a reassessment after 10 years", Public Administration, Vol. 91 No. 3, pp. 521-543.

Vogel, R. and Werkmeister, L. (2021), "What is public about public leadership? Exploring implicit public leadership theories", Journal of Public Administration Research and Theory, Vol. 31 No. 1, pp. 166-183.

Wilson, S. (2016), Thinking Differently about Leadership: A Critical History of Leadership Studies, Elgar Publishing, Cheltenham.

Wright, B.E., Moynihan, D.P. and Pandey, S.K. (2012), "Pulling the levers: transformational leadership, public service motivation and mission valence", Public Administration Review, Vol. 72 No. 2, pp. 206-215.

\section{Further reading}

Hartley, J., Parker, S. and Beashel, J. (2019), "Leading and recognizing public value", Public Administration, Vol. 97, pp. 264-278.

Moore, M.H. (2013), Recognizing Public Value, Harvard University Press, Cambridge, MA. 